UTILITY: Jurnal IImiah Pendidikan dan Ekonomi

Volume 3, No. 1, Februari 2019: Page 29-44

ISSN 2549-1377 (Print) || ISSN 2549-1385 (Online)

Available online at http://journal.stkipnurulhuda.ac.id/index.php/utility

\title{
PENGARUH IKLAN DAN KELOMPOK REFERENSI TERHADAP PERILAKU KONSUMSI MAHASISWA PROGAM STUDI PENDIDIKAN EKONOMI UNIVERSITAS BATANGHARI
}

\author{
Nur Melianty. $S^{1 *}$, Suratno ${ }^{2}$, dan Ali Idrus ${ }^{3}$ \\ ${ }^{1,2,3}$ Universitas Jambi \\ *E-mail: Nurmeliantys@yahoo.com
}

\begin{abstract}
Abstrak:Penelitian ini bertujuan untuk mengetahui pengaruh iklan dan kelompok referensi terhadap perilaku konsumsi mahasiswa Progam Studi Pendidikan Ekonomi Universitas Batanghari. Penelitian ini menggunakan jenis penelitian ekplanatori. Metode pengumpulan data yang digunakan yaitu angket, yang dibagikan pada 49 responden yaitu mahasiswa Progam Studi Pendidikan Ekonomi Universitas Batanghari. Hasil penelitian menunjukkan bahwa teRdapat pengaruh simultan iklan dan kelompok referensi terhadap perilaku konsumsi. Secara parsialiklan berpengaruh terhadap perilaku konsumsi mahasiswa sebesar 0.696 yang berarti terdapat pengaruh kuat dan signfikan iklan terhadap perilaku konsumsi, dan kelompok referensi berpengaruh terhadap perilaku konsumsi mahasiswa sebesar 0.681yang berarti terdapat pengaruh kuat dan signifikan kelompok referensi terhadap perilaku konsumsi mahasiswa Prodi Pendidikan Ekonomi Universitas Batanghari.
\end{abstract}

Kata Kunci: Iklan, Kelompok Referensi, Perilaku Konsumsi

\section{PENDAHULUAN}

Saat ini kita memasuki era revolusi industri 4.0, disertai dengan perkembangan teknologi yang semakin canggih dengan menekankan pada pola digital economy. Ekonomi digital telah mengubah mindset para pelaku bisnis di era revolusi industri 4.0 dengan hadirnya bisnis start-up pada transportasi online seperti Gojek, Grab, Uber. Transportasi online ini menawarkan beragam kemudahan dan efisiensi waktu bagi penggunanya, karena dapat memesan jasa transportasi, kuliner, bahkan pengantaran berkas atau dokumen hanya melalui smartphone. Tidak hanya itu, media sosial juga turut berperan besar di tengah booming ekonomi digital. Dengan media sosial, masyarakat semakin mudah untuk mengidentifikasi dan mendapatkan beragam produk terbaik secara online. Tidak harus datang ke toko untuk membeli produk fashion yang dibutuhkan, tetapi cukup memesan secara online kemudian pesanan akan dikirim ke alamat yang tertera. Perilaku konsumen saat ini juga banyak mengalami perubahan seiring dengan perkembangan dunia usaha. 
Perkembangan dunia usaha yang pesat dengan dipicu perkembangan teknologi mendorong sektor industri barang dan jasa baik yang berskala besar maupun berskala kecil untuk berkompetisi dalam persaingan pasar. Hal ini mendorong para pelaku usaha untuk terus menciptakan produk yang inovatif serta memberikan tingkat efisiensi yang tinggi bagi penggunanya. Tidak hanya itu, untuk memenangkan persaingan pasar produsen melakukan berbagai strategi promosi produk. Promosi produk merupakan strategi bagi para produsen dalam memasarkan produknya agar masyarakat tertarik untuk membeli. Strategi yang biasanya dilakukan oleh produsen adalah iklan. Tjiptono (2005) mengatakan bahwa, "iklan adalah bentuk komunikasi tidak langsung yang didasari pada informasi tentang keunggulan atau keuntungan suatu produk, yang disusun sedemikian rupa sehingga menimbulkan rasa menyenangkan yang akan mengubah pikiran seseorang untuk melakukan pembelian".

Tidak jarang sekarang kita melihat dipinggir jalan besar terpampang baleho yang menawarkan beragam produk untuk menarik konsumen. Terlebih lagi media sosial seperti Instagram, dari hasil observasi pada mahasiswa Universitas Batanghari Progam Studi Pendidikan Ekonomi sebagian besar mahasiswa memiliki smarphone dan memiliki aplikasi Instagram dalam smartphonenya. Hal ini dimanfaatkan mahasiswa untuk menggunakannya ketika waktu luang di kampus hingga di rumah. Dalam aplikasi ini banyak sekali menampilkan tayangan iklan tentang beragam jenis produk fashion yang menarik sehingga membuat mahasiswa untuk melakukan pembelian.

Menurut Kotler (2006) terdapat beberapa faktor perilaku konsumen yang mempengaruhi proses pengambilan keputusan yaitu faktor budaya, faktor sosial, faktor pribadi dan faktor psikologi. Faktor sosial terdiri dari kelompok acuan atau kelompok referensi, keluarga, serta peran dan status. Kelompok referensi menjadi salah satu pertimbangan konsumen dalam mengambil keputusan berkonsumsi. Setiap hari mahasiswa akan sering bertemu dan bergaul dengan teman kelompok atau publik figur yang menjadi referensi dalam melakukan keputusan pembelian. Mahasiswa dalam hal ini menjadi subjek dalam penelitian, mulai menjalani proses kehidupan yang mandiri dimana pada saat ini mereka berada dalam rentang usia remaja akhir. Selain jauh dari keluarga khususnya bagi mahasiswa rantau, mahasiswa harus bisa hidup mandiri dengan uang saku yang ada. Mahasiswa yang dididik 
sebagai calon pendidik harus bisa memanajemen keuangannya sehingga tidak berlebihan dalam penggunaan uang saku.

Berdasarkan survei dari peneliti terhadap mahasiswa Universitas Jambi, diperoleh informasi bahwa mahasiswa sudah memiliki smartphone yang menunjang kebutuhan hidup mahasiswa, selain itu pergaulan dengan teman yang cenderung memiliki geng-geng atau kelompok bermain sendiri di dalam kelas. Ditambah lagi lokasi kampus yang dekat dengan pusat perbelanjaan serta mudahnya akses informasi yang didapat mahasiswa dari mana saja. Hal ini akan mempengaruhi perilaku konsumsi mahasiswa.

Secara umum tujuan penelitian untuk mengetahui pengaruh (1) Iklan terhadap perilaku konsumsi mahasiswa (2) Kelompok referensi terhadap perilaku konsumsi mahasiswa Progam Studi Pendidikan Ekonomi Universitas Batanghari.

\section{METODE}

Penelitian ini menggunakan pendekatan kuantitatif bersifat deskriptif dengan jenis penelitian ekplanatori untuk menjelaskan ada tidaknya pengaruh dan jika ada pengaruh seberapa besar pengaruh variabel bebas iklan (X1) dan kelompok referensi (X2) terhadap variabel terikatperilaku konsumsi (Y). Sampel penelitian ini sebanyak 49 mahasiswa Progam Studi Pendidikan Ekonomi Universitas Batanghari yang beralamat di Jl. Slamet Riyadi NO. 01 Sungai Putri Telanaipura Jambi.Penelitian ditujukan pada masiswa semester I dan II karena mahasiswa sudah mempelajari mata pelajaran ekonomi dasar yang berhubungan dengan kebutuhan, kelangkaan, dan biaya peluang sehingga dianggap mahasiswa sudah memahami serta dapat menerapkan dalam perilakunya sehari-hari.

\section{HASIL DAN PEMBAHASAN Hasil Penelitian}

Hasil penelitian menunjukkan bahwa iklan pada Mahasiswa Progam Studi Pendidikan Universitas Batanghari berada dalam kategori tinggi dengan nilai mean sebesar 58.90 dengan nilai maksimum 69 dan nilai minimum 48, kelompok referensi berada pada kategori tinggi dengan nilai mean sebesar 
34.88 dengan nilai maksimum 44 dan nilai minimum 28, dan perilaku konsumsi berada pada kategori tinggi dengan nilai mean sebesar 77.39 dengan nilai maksimum 91 dan nilai minimum 64 yang di artikan memiliki perilaku konsumsi mengarah pada perilaku konsumtif.

Uji asumsi klasik yang dilakukan pada penelitian ini yaitu uji normalitas menggunakan grafik P-P Plot of Regression Standardized Residual bahwa penelitian ini berdistribusi normal. Hal ini ditunjukkan dengan data menyebar di sekitar garis diagonal dan mengikuti arah garis diagonal. Kemudian uji multikolinieritas dapat dilihat dari nilai VIF (Variance Inflation Factor) dan nilai Tolerance, bahwa pada penelitian ini tidak terjadi multikolinieritas dilihat dari variabel bebas memiliki nilai VIF sebesar 1.752 > 10 atau nilai Tolerance sebesar $0.571<10$. Selanjutnya uji heterokedastisitas yang dilihat dari nilai Sig. variabel iklan sebesar $0.962>0.05$ dan variabel kelompok referensi sebesar $0.889>0.05$, sehingga disimpulkan model regresi tidak terjadi heterokedastisitas.

\section{a. Hipotesis statistik pengaruh iklan terhadap perilaku konsumsi}

\section{Tabel 1}

\section{Uji Parsial Iklan}

Coefficients $^{\mathrm{a}}$

\begin{tabular}{|c|c|c|c|c|c|}
\hline \multirow[b]{2}{*}{ Model } & \multicolumn{2}{|c|}{$\begin{array}{c}\text { Unstandardized } \\
\text { Coefficients }\end{array}$} & \multirow{2}{*}{$\begin{array}{c}\begin{array}{c}\text { Standardized } \\
\text { Coefficients }\end{array} \\
\text { Beta } \\
\end{array}$} & \multirow[b]{2}{*}{$\mathrm{t}$} & \multirow[b]{2}{*}{ Sig. } \\
\hline & $\mathrm{B}$ & Std. Error & & & \\
\hline $1 \quad$ (Constant) & 27.434 & 6.679 & & 4.108 & .000 \\
\hline Iklan & .808 & . 122 & .696 & 6.649 & .000 \\
\hline
\end{tabular}

Berdasarkan hasil perhitungan dalam tabel di atas menunjukkan bahwa terdapat pengaruh iklan terhadap perilaku konsumsi sebesar 0.696, dengan nilai signifikansi 0.000 . Dengan persamaan $\mathrm{Y}=\mathrm{a}+\mathrm{bX}_{1}+\mathrm{e}$, atau $\mathrm{Y}=27.434+0.696 \mathrm{X}_{1}+\mathrm{e}$, yang berarti setiap penambahan iklan sebesar 1 maka akan berpengaruh pada kenaikan perilaku konsumsi sebesar 0.696. Dapat diketahui hasil Uji t sebesar 6.649 sedangkan $t_{\text {tabel }}$ sebesar 1.677 maka $6.649>1.677$ berarti terdapat pengaruh iklan terhadap perilaku konsumsi. 


\section{b. Hipotesis statistik pengaruh kelompok referensi terhadap perilaku konsumsi}

Tabel 2

Uji Parsial Kelompok Referensi

Coefficients $^{\mathrm{a}}$

\begin{tabular}{|c|c|c|c|c|c|}
\hline \multirow[b]{2}{*}{ Model } & \multicolumn{2}{|c|}{$\begin{array}{c}\text { Unstandardized } \\
\text { Coefficients }\end{array}$} & \multirow{2}{*}{$\begin{array}{c}\text { Standardized } \\
\text { Coefficients }\end{array}$} & \multirow[b]{2}{*}{$\mathrm{t}$} & \multirow[b]{2}{*}{ Sig. } \\
\hline & $\mathrm{B}$ & Std. Error & & & \\
\hline $1 \quad$ (Constant) & 31.484 & 6.332 & & 4.972 & .000 \\
\hline $\begin{array}{l}\text { Kelompok } \\
\text { Referensi }\end{array}$ & 1.225 & .192 & .681 & 6.378 & .000 \\
\hline
\end{tabular}

a. Dependent Variable: Perilaku Konsumsi

Berdasarkan hasil perhitungan dalam tabel di atas menunjukkan bahwa terdapat pengaruh kelompok referensi terhadap perilaku konsumsi sebesar 0.681, dengan nilai signifikansi 0.000. Dengan persamaan $\mathrm{Y}=\mathrm{a}+\mathrm{bX} 2+\mathrm{e}$, atau $\mathrm{Y}=31.484+0.681 \mathrm{X}_{2}+\mathrm{e}$, yang berarti setiap penambahan kelompok referensi sebesar 1 maka akan berpengaruh pada kenaikan perilaku konsumsi sebesar 0.681. Dapat diketahui hasil Uji t sebesar 6.378 sedangkan $t_{\text {tabel }}$ sebesar 1.677 maka $6.378>1.677$ berarti terdapat pengaruh kelompok referensi terhadap perilaku konsumsi.

\section{c. Hipotesis statistik pengaruh secara simultan iklan dan kelompok referensi terhadap perilaku konsumsi}

\section{Tabel 3}

\section{Uji Simultan Iklan dan Kelompok Referensi}

Model Summary ${ }^{\mathrm{b}}$

\begin{tabular}{|c|c|c|c|c|c|}
\hline Model & $\mathrm{R}$ & R Square & $\begin{array}{c}\text { Adjusted R } \\
\text { Square }\end{array}$ & $\begin{array}{c}\text { Std. Error of the } \\
\text { Estimate }\end{array}$ & Durbin-Watson \\
\hline 1 & $.757^{\mathrm{a}}$ & .573 & .555 & 6.267280 & 1.906 \\
\hline
\end{tabular}

a. Predictors: (Constant), Kelompok Referensi, Iklan

b. Dependent Variable: Perilaku Konsumsi

ANOVA $^{\mathrm{a}}$

\begin{tabular}{|l|r|r|r|r|r|}
\hline Model & Sum of Squares & \multicolumn{1}{c|}{ df } & Mean Square & F & \multicolumn{1}{c|}{ Sig. } \\
\hline Regression & 2428.612 & 2 & 1214.306 & 30.915 & $.000^{\mathrm{b}}$ \\
Residual & 1806.825 & 46 & 39.279 & & \\
Total & 4235.437 & 48 & & & \\
\hline
\end{tabular}

a. Dependent Variable: Perilaku Konsumsi

b. Predictors: (Constant), Kelompok Referensi, Iklan 
Berdasarkan hasil perhitungan dalam tabel di atas menunjukkan bahwa terdapat pengaruh secara simultan iklan dan kelompok referensi terhadap perilaku konsumsi sebesar 0.757 pada signifikansi sebesar 0.000 atau dapat dilihat pada nilai $\mathrm{F}_{\text {hitung }}$ sebesar $30.915>3.20$.

\section{Tabel 4}

Uji Regresi Berganda

Coefficients $^{\mathrm{a}}$

\begin{tabular}{|c|c|c|c|c|c|c|c|}
\hline \multirow[b]{2}{*}{ Model } & \multicolumn{2}{|c|}{$\begin{array}{l}\text { Unstandardized } \\
\text { Coefficients }\end{array}$} & \multirow{2}{*}{$\begin{array}{c}\begin{array}{c}\text { Standardized } \\
\text { Coefficients }\end{array} \\
\text { Beta }\end{array}$} & \multirow[b]{2}{*}{$\mathrm{t}$} & \multirow[b]{2}{*}{ Sig. } & \multicolumn{2}{|c|}{ Collinearity Statistics } \\
\hline & B & Std. Error & & & & Tolerance & VIF \\
\hline 1 (Constant) & 20.649 & 6.523 & & 3.166 & .003 & & \\
\hline Iklan & .509 & .148 & .438 & 3.436 & .001 & .571 & 1.752 \\
\hline $\begin{array}{l}\text { Kelompok } \\
\text { Referensi }\end{array}$ & .709 & .229 & .394 & 3.092 & .003 & .571 & 1.752 \\
\hline
\end{tabular}

a. Dependent Variable: Perilaku Konsumsi

Berdasarkan hasil perhitungan dalam tabel di atas maka dapat disusun persamaan regresi berganda yaitu $\mathrm{Y}=\mathrm{\alpha}_{0}+\mathrm{b}_{1 \mathrm{x} 1}+\mathrm{b}_{2 \times 2}+\mathrm{e}$ yaitu $\mathrm{Y}=20.649+$ $0.509 \mathrm{X}_{1}+0.709 \mathrm{X}_{2}+$ e. Model persamaan regresi berganda tersebut dapat menjelaskan bahwa, apabila variabel bebas yaitu iklan mengalami kenaikan sebesar 1 maka akan diikuti dengan kenaikan perilaku konsumsi sebesar 0.509 satuan. Sedangkan apabila variabel bebas kelompok referensi mengalami kenaikan sebesar 1 maka akan diikuti dengan kenaikan perilaku konsumsi sebesar 0.709 satuan.

\section{Pembahasan}

Berdasarkan hasil penelitian diketahui bahwa iklan merupakan media yang sering digunakan oleh mahasiswa sebelum memutuskan untuk berkonsumsi. Mahasiswa sebagian besar sering memanfaatkan media iklan untuk mencari informasi keunggulan produk. Hal ini terlihat dari analisis deskriptif iklan berada pada kategori tinggi. Iklan memberikan pengaruh dalam perilaku konsumsi mahasiswa yang mengarahkan pada perilaku konsumtif mahasiswa. Hal ini terlihat dari intensitas mahasiswa dalam melihat iklan lebih dari 6 kali dalam sehari. Pemilihan media iklan yang tepat dengan tampilan yang menarik membuat mahasiswa mudah terpengaruh untuk membeli produk yang ditampilkan dalam iklan. Selain itu iklan yang ditampilkan memberikan daya tarik terhadap keunggulan produk ditambah lagi iklan yang memberikan penawaran khusus seperti diskon, sale, dan 
doorprice yang membuat mahasiswa terdorong untuk melakukan pembelian tanpa melihat penting tidaknya produk tersebut.

Menurut Morissan (2010) iklan merupakan salah satu bentuk promosi yang paling dikenal dan paling banyak dibahas orang, hal ini kemungkinan karena daya jangkauannya yang luas. Terlebih lagi saat ini iklan dapat dengan mudah dilihat dalam media online. Jangkauan media onlineyang sangat luas dapat dengan mudah dijangkau oleh masyarakat luas khususnya pada mahasiswa, karena sebagian besar mahasiswa sudah memiliki smartphone yang memiliki fitur-fitur aplikasi media online yang menawarkan beragam jenis produk yang selalu uptodate. Penelitian ini sejalan dengan penelitian yang dilakukan oleh Wulandari dkk (2016) iklan mempunyai persentase tertinggi terhadap perilaku konsumsi siswa, dapat dilihat dari perilaku siswa yang terpengaruh membeli suatu produk baru yang diiklankan oleh produsen baik itu melalui media cetak maupun media elektronik.

Iklan dalam penelitian ini memberikan pengaruh positif kepada perilaku konsumsi, semakin mahasiswa tertarik untuk membeli suatu produk yang dipengaruhi oleh rasa ingin tahu yang tinggi serta mengikuti trend yang sedang booming maka semakin mudah mahasiswa terpengaruh iklan dalam berkonsumsi sehingga ada keinginan untuk membeli produk yang diiklankan, hal tersebut akan mengarahkan pada perilaku konsumtif. Perilaku konsumtif begitu dominan dikalangan remaja (Sumartono, 2002). Sifat-sifat remaja dalam hal ini mahasiswa yang cenderung mudah terbujuk rayuan iklan terutama iklan yang memberikan keunggulan serta tampilan yang menarik atas suatu produk, sifat tidak realistis dan cenderung boros dalam menggunakan uang sakunya. Hal ini mendukung teori yang dikemukakan oleh Kertamukti (2015) dari sekian banyak iklan yang ada tujuannya adalah sama yaitu mendekati khalayak sasaran mereka serta mengajak khalayak untuk membeli atau menggunakan produk atau jasa yang mereka tawarkan.

Iklan selalu menampilkan sisi keunggulan suatu produk yang dikemas sedemikian rupa sehingga menarik konsumen untuk tertarik membeli atau menggunakan produk tersebut yang diiklankan. Hal inilah yang membuat mahasiswa Prodi Pendidikan Ekonomi Universitas Jambi seringkali terbujuk oleh tawaran produk yang terdapat dalam ikan.

Kelompok referensi berpengaruh terhadap perilaku konsumsi mahasiswa, hal ini telihat dari sebagian besar mahasiswa menjadikan 
kelompok referensi sebagai rujukan dalam perilaku konsumsinya. Kelompok referensi dalam penelitian ini merujuk pada publik figur yang menjadi referensi mahasiswa dalam berkonsumsi. Menurut Peter dan Olson (2000) kelompok referensi melibatkan satu atau lebih orang yang dijadikan sebagai dasar pembanding atau titik referensi dalam membentuk tanggapan atau afeksi dan kognisi serta menyatakan perilaku seseorang. Dalam penelitian ini kelompok referensi berada dalam kategori tinggi yang dan berpengaruh positif terhadap perilaku konsumsi mahasiswa. Hal ini berarti apabila semakin tinggi pengaruh kelompok referensi dalam keputusan berkonsumsi, maka semakin tinggi pula perilaku konsumsi mahasiswa yang mengarahkan pada perilaku konsumtif.

Pola perilaku konsumtif memiliki beberapa indikator yaitu: 1) Membeli produk karena iming-iming hadiah, 2) Membeli produk karena kemasannya menarik, 3) Membeli produk demi menjaga penampilan gengsi, 4) Membeli produk berdasarkan pertimbangan harga (bukan atas dasar manfaat), 5) Membeli produk hanya sekedar manjaga simbol dan status, 6) Memakai produk karena unsur konformitas terhadap model yang mengiklankan produk, 7) Munculnya penilaian bahwa membeli produk dengan harga mahal akan menimbulkan rasa percaya diri, 8) Keinginan mencoba lebih dari dua produk sejenis berbeda (Sumartono, dalam Sukari, dkk: 2013). Karena itulah munculnya perilaku konsumtif dalam berkonsumsi. Mahasiswa cenderung membeli suatu produk barang atau jasa karena dorongan nafsu dan pengaruh dari lingkungan salah satunya kelompok referensi yang ada di dalam iklan.

Kelompok referensi menjadi acuan mahasiswa dalam berkonsumsi yaitu memberikan informasi dan membentuk kepercayaan mahasiswa terhadap suatu produk yang ditawarkan atau yang digunakannya. Sebelum memutuskan untuk membeli suatu produk biasanya mahasiswa mencari terlebih dahulu kelompok referensi atau publik figur yang menggunakan produk tersebut. Selain untuk mendapatkan hasil yang memuaskan sesuai dengan keinginan, mahasiswa juga merasa bangga jika membeli produk sama dengan yang digunakan publik figur idolanya. Hasil penelitian ini mendukung penelitian yang dilakukan oleh Fitriyah (2013) kelompok acuan berpengaruh signifikan terhadap keputusan pembelian batik tulis Jetis pada toko Amri Jaya Sidoarjo, artinya kelompok acuan baik secara langsung maupun tidak langsung memberikan dorongan bagi konsumen untuk membeli batik tulis Jetis. 
Dari hasil temuan dilapangan pemanfaatan smartphone yang dimiliki mahasiswa lebih sering digunakan untuk mencari tahu informasi tentang mode fashion yang sedang hits saat ini, khususnya pada kalangan wanita. Mahasiswa sering menggunakan smartphone untuk membuka aplikasi instagram, yang didalamnya banyak menawarkan iklan produk fashion yang sedang hits. Mahasiswa cenderung membuka toko-toko online dan mengikuti artis atau publik figur yang menjadi referensi dalam berkonsumsi. Tawaran dari iklan dan publik figur inilah yang mempengaruhi perilaku konsumsi mahasiswa. Sehingga mahasiswa cenderung tidak rasional dalam berkonsumsi karena mengikuti tren dari publik figur yang menawarkan produk-produk yang menarik.

\section{SIMPULAN}

Berdasarkan hasil penelitian, maka kesimpulan yang dapat ditarik dari penelitian ini adalah terdapat pengaruh kuat dan signifikan iklan terhadap perilaku konsumsi mahasiswa Progam Studi Pendidikan Ekonomi Universitas Batanghari. Perilaku konsumsi yang dipengaruhi iklan mengarahkan pada perilaku konsumtif. Mahasiswa cenderung terpengaruh ikan dalam berkonsumsi, karena iklan menawarkan beragam produk yang dibutuhkan oleh mahasiswa. Selain itu informasi, penempatan dan media yang digunakan dalam iklan membuat mahasiswa tertarik untuk melakukan pembelian atas produk yang diiklankan. Karena sebagian besar mahasiswa memiliki smartphone yang memiliki aplikasi media online yang memberikan beragam jenis pilihan barang konsumsi yang akan mempengaruhi perilaku konsumsinya.

Terdapat pengaruh kuat dan signifikan kelompok referensi terhadap perilaku konsumsi mahasiswa Progam Studi Pendidikan Ekonomi Universitas Batanghari. Kelempok referensi memberikan pengaruh mahasiswa dalam berkonsumsi produk barang dan jasa karena publik figur yang mereka lihat dapat memberikan informasi tentang suatu produk yang akan dikonsumsi. Selain itu kelompok referensi memberikan pengaruh terhadap kepercayaan diri mahasiswa yang menggunakan produk sama seperti dengan yang digunakan publik figur atau kelompok referensinya. 


\section{SARAN}

Saran yang penulis berikan bagi pihak (1) Produsen atau pemasar yaitu memberikan informasi yang menarik tentang suatu produk yang ditawarkan agar konsumen merasa yakin bahwa produk tersebut adalah produk yang tepat. Selain itu produsen harus terus meningkatkan kretivitas dan inovasi produk untuk memenuhi permintaan konsumen yang semakin kritis terhadap pemilihan suatu produk; (2) Mahasiswa agar dapat menjadi rujukan dalam berperilaku konsumsi yang baik, iklan dan kelompok referensi yang berpengaruh dalam membeli suatu produk dapat digunakan dengan baik untuk mencari informasi dan keunggulan suatu produk agar mahasiswa tidak mudah terbujuk rayuan iklan dan kelompok referensinya; (3) Peneliti lain dapat dijadikan masukan ataupun menambah rujukan untuk penelitian selanjutnya yang terkait dengan iklan dan kelompok referensi terhadap perilaku konsumsi sehingga berguna sebagai tambahan pengetahuan, kajian dan referensi untuk permasalahan yang terkait dengan masalah dalam penelitian ini. Selanjutnya bagi peneliti lain untuk dapat memperluas variabel lain diluar variabel yang digunakan dalam penelitian ini.

\section{UCAPAN TERIMAKASIH}

Ucapan terimakasih ditujukan kepada Fakultas Keguruan dan Ilmu Pendidikan Progam Studi Pendidikan Ekonomi Universitas Batanghari Jambi, Tim Jurnal Utility STKIP Nurul Huda.

\section{REFERENSI}

Fitriyah, Nikmatul 2013. Pengaruh Kelompok Acuan dan Keluarga Terhadap Keputusan Pembelian Batik Tulis Jetis Pada Toko Amri Jaya Sidoarjo. Jurnal Universitas Negeri Surabaya.

Kertamukti, Rama. 2015. Strategi Kreatif dalam Periklanan. Jakarta: Rajawali Pers.

Kotler, Philip. 2006. Manajemen Pemasaran: Jakarta: PT.Prehallindo.

Morissan. 2010. Periklanan Komunikasi Pemasaran Terpadu. Jakarta: Kencana. 
Pengaruh Iklan Dan Kelompok Referensi Terhadap Perilaku Konsumsi Mahasiswa Progam Studi Pendidikan Ekonomi Universitas Batanghari

Tjiptono, Fandy. 2005. Strategi Pemasaran Edisi Kedua. Yogykarta: Andi.

Peter, J. Paul dan Jerry C. Olson. 2000. ConsumerBehavior: Perilaku KonsumendanStrategi Pemasaran Edisi Kesembilan. Jakarta:Erlangga.

Sumartono. 2002. Terperangkap dalam Iklan (Meneropong Imbas Pesan Iklan Televisi). Bandung: Alfabeta.

Sukari, dkk. 2013. Perilaku Konsumtif Siswa SMA di Daerah Istimewa Yogyakarta. Yogyakarta: Balai Pelestarian Nilai Budaya Yogyakarta.

Wulandari, Fitri dkk. 2016. Pengaruh Perhatian Orang Tua, Respon Pada Iklan, Intensitas Pergaulan Teman Sebaya, dan Pemahaman Siswa Pada Mata Pelajaran Ekonomi Terhadap Perilaku Konsumsi Siswa Kelas VII SMPN 2 Nglegok Kabupaten Blitar. Jurnal Pendidikan Ekonomi, (Online), Vol.9 No.2, journal2.um.ac.id/index.php/jpe/article/view/1607 